\title{
Peningkatan Ketrampilan Membuat Minuman Jasule untuk Imunitas Dimasa Pandemi Covid-19 Di Pangkalan Jati Cinere Depok
}

\author{
Tiwuk Susantiningsih" ${ }^{*}$, Yuni Setyaningsih², Agneta Irmarahayu ${ }^{3}$, Fajriati Zulfa ${ }^{4}$ \\ Fakultas Kedokteran UPN Veteran Jakarta ${ }^{1,2,3,4}$ \\ tiwuksusantiningsih@gmail.com ${ }^{1}$, yunisty00@gmail.com ${ }^{2}$, agnetairawan@gmail.com ${ }^{3}$, zulfafajriati@yahoo.com ${ }^{4}$
}

\begin{abstract}
During the Covid-19 pandemic, good immunity was needed to avoid the corona virus infection. One of the efforts to prevent corona virus infection was to increase the body's immune status. One local wisdom of the people in Indonesia to increasing immunity level was the habit of consuming herbal drinks which were believed to increase immunity level. One of the herbal drinks made from ginger and lemon was Jasule (Jahe Susu Lemon). In this training, the participants were given material about the importance of the herbal drink Jasule, also given training in making Jasule drink until all participants can make it themselves. The training activities for making herbal drinks Jasule to increase body immunity level during the Covid-19 Pandemic were held in Pangkalan Jati Cinere, Depok. This activity was well received by all participants with enthusiasm and the questions asked. Participants gained additional knowledge and skills in making herbal drinks Jasule, which can be seen from the increasing in post test scores after counseling and training in making herbal drink Jasule to increasing body immunity level during the Covid-19 Pandemic in Pangkalan Jati Cinere, Depok was $42.4 \%$ ie from $47.9 \%$ to $90.3 \%$.
\end{abstract}

Keywords: Immunity; Jasule herbal drink; Ginger Lemon Milk; Covid-19 Pandemic.

\begin{abstract}
Abstrak
Dimasa pandemi Covid-19 ini, imunitas yang baik sangat diperlukan untuk menghindari tertularnya infeksi virus corona. Salah satu upaya mencegah infeksi virus corona adalah dengan meningkatkan status imunitas tubuh. Salah satu minuman herbal yang berasal dari bahan jahe dan lemon adalah JASULE yaitu minuman jahe susu dengan ditambahkan lemon. Dalam pelatihan ini peserta penyuluhan diberikan materi tentang pentingnya kandungan minuman herbal Jasule (Jahe Susu Lemon). Pentingnya menanam jahe dan lemon sebagai salah satu tanaman obat di pekarangan. Serta diberikan pelatihan pembuatan minuman Jahe Susu Lemon sampai semua peserta benar benar bisa membuatnya sendiri. Kegiatan penyuluhan dan pelatihan pembuatan minuman herbal Jasule untuk meningkatkan imunitas tubuh dimasa Pandemi Covid-19 dilaksanakan di Desa Pangkalan Jati Cinere Depok. Kegiatan ini dapat diterima dengan baik oleh peserta penyuluhan terlihat dengan antusiasme dan pertanyaan yang diajukan. Peserta mendapatkan tambahan pengetahuan dan ketrampilan dalam membuat minuman herbal Jasule dapat dilihat dengan terdapatnya peningkatan nilai post test setelah dilakukan penyuluhan dan pelatihan pembuatan minuman herbal Jasule Jahe Susu Lemon untuk meningkatkan imunitas
\end{abstract}


tubuh dimasa Pandemi Covid-19 di Desa Pangkalan Jati Cinere Depok sebesar 42,4\% yaitu dari 47,9\% menjadi $90,3 \%$.

Kata Kunci: Imunitas Tubuh; Minuman herbal Jasule; Jahe Susu Lemon; Pandemi Covid-19.

\section{A. PENDAHULUAN}

Virus corona merupakan keluarga besar virus yang menyebabkan infeksi saluran pernapasan atas ringan hingga sedang, seperti penyakit influenza. Beberapa jenis virus corona bisa menimbulkan penyakit yang lebih serius, seperti MERSCoV, SARS-CoV dan Pneumonia. Covid-19 atau dikenal juga dengan Novel Coronavirus adalah virus yang menyebabkan wabah pneumonia di kota Wuhan, Tiongkok pada Desember 2019, dan menyebar ke negara lainnya mulai Januari 2020. Indonesia sendiri mengumumkan adanya kasus Covid-19 dari bulan Maret tahun 2020 (Kemenkes, 2020) (Susilo et al., 2020).

Setiap orang bisa terinfeksi virus corona. Akan tetapi, bayi dan anak kecil, serta orang dengan kekebalan tubuh yang lemah lebih rentan terhadap serangan virus ini. Selain itu, kondisi musim juga mungkin berpengaruh terhadap infeksi virus ini (Susilo et al., 2020).

Infeksi virus corona kebanyakan dapat menyebar seperti virus lain pada umumnya, misalnya dengan cara percikan air liur pengidap lewat bantuk dan bersin, menyentuh tangan atau wajah orang yang terinfeksi, menyentuh mata, hidung, atau mulut setelah memegang barang yang terkena percikan air liur pengidap virus corona (UNICEF, 2020).

Salah satu upaya mencegah infeksi virus corona adalah dengan meningkatkan status imunitas tubuh. Imunitas tubuh yang baik bisa didapatkan dari mengkonsumsi makanan sehat, istirahat yang cukup dan menghindari stress/tekanan batin. Satu kearifan lokal masyarakat di Indonesia dalam meningkatkan imunitas adalah kebiasaan mengkonsumsi minuman herbal yang dipercaya dapat meningkatkan imunitas tubuh karena terdapat beberapa kandungan yang sangat bermanfaat. Misalnya mengkonsumsi minuman yang berasal dari bahan jahe dan lemon dengan ditambahkan susu. Minuman ini dikenal dengan JaSuLe (Jahe Susu Lemon) (Kusuma et al., 2020).

Desa Pangkalan Jati adalah salah satu desa yang ada di Kecamatan Cinere Kota Depok Jawa Barat. Dari survey pendahuluan yang dilakukan pada Bulan Mei 2020 bahwa masyarakat Desa Pangkalan Jati belum pernah membuat minuman tradisional Jasule Jahe susu lemon. Berikut beberapa permasalahan mitra yang ditemui yaitu banyak terdapat bahan rempah di sekitar lingkungan Desa Pangkalan Jati, tingkat pengetahuan masyarakat tentang pemanfaatan bahan herbal masih rendah, ketrampilan ibu ibu tentang pemanfaatan tanaman herbal masih rendah, ketrampilan ibu ibu tentang pembuatan minuman herbal JaSuLe masih rendah dan belum adanya pelatihan ketrampilan pembuatan minuman herbal di Desa Pangkalan Jati Cinere Depok.

Berdasarkan permasalahan mitra diatas, maka Tim Pengabdian Kepada Masyarakat Universitas Pembangunan "Veteran" Jakarta berniat untuk melakukan Program Kemitraan Masyarakat (PKM) tentang PKM peningkatan pengetahuan dan ketrampilan membuat minuman JaSuLe (jahe susu lemon) pada masyarakat untuk meningkatkan imunitas tubuh guna mencegah penularan penyakit Covid19 di Desa Pangkalan Jati Cinere Depok. 
Oleh karena itu Tim Pengabdian Kepada Masyarakat Fakultas Kedokteran UPN Veteran Jakarta bekerjasama dengan Program Kemitraan Masyarakat memberikan penyuluhan dan pelatihan pembuatan minuman Jasule Jahe Susu Lemon untuk meningkatkan imunitas tubuh dalam menghadapi pandemi Covid-19.

Manfaat kegiatan ini bagi dosen adalah untuk dapat melaksanakan salah satu dharma dari Tri Dharma Perguruan Tinggi yakni pengabdian kepada masyarakat. Untuk mencapai pengembangan potensi diri, pemberdayaan masyarakat dan pengembangan institusi. Menambah pengalaman bekerja secara tim dan pengkajian, penemuan masalah dan pemecahan masalah secara langsung, sehingga meningkatkan rasa empati dan sikap profesionalisme dalam diri dan peningkatan keahlian, tanggungjawab dalam suatu tim kerja yang solid. Menjadikan citra dokter dimata masyarakat lebih baik dan dapat sebagai motivator dan pembawa perubahan dalam hal kesehatan masyarakat. Memperoleh pengalaman da lam menumbuhkan potensi swadaya masyarakat, sehingga mampu berpartisipasi aktif dalam peningkatan derajat kesehatan masyarakat.

Bagi Institusi UPN Veteran Jakarta. Membantu dokter/petugas kesehatan dalam memberikan pelatihan dan penyuluhan untuk mencapai program bidang Kesehatan. Memperoleh berbagai kasus yang dapat digunakan sebagai contoh materi perkuliahan, edukasi, mencari penyelesaian berbagai masalah untuk pengembangan penelitian dan pengabdian bagi masyarakat, serta dapat mendekatkan lembagapendidikan perguru an tinggi kemasyarakat serta membantu pemerintah dalam meningkatkan kwalitas kesehatan dan mempersiapkan kader- kader pelaku peningkatan kesehatan yang berkualitas di masyarakat.

\section{B. PELAKSAAAN DAN METODE}

Pada pelaksanaan kegiatan PKM ini, langkah pertama, tim Pengabdian Masyarakat Fakultas Kedokteran Universitas Pembangunan Nasional "Veteran" Jakarta melakukan pengkajian dengan survey pendahuluan kepada Masyarakat Desa Pangkalan Jati Cinere Depok. Berdasarkan survey tersebut didapatkan beberapa permasalahan yang dihadapi di Desa Pangkalan Jati Cinere Depok.

Langkah kedua, menyusun permasalahan berdasarkan urutan masalah yang paling penting dan perlu mendapatkan solusi segera. Pada langkah ini perlu berkoordinasi dengan pihak terkait, mengenai kemungkinan solusi yang paling mungkin dilaksanakan. Langkah ketiga adalah pelaksaan solusi yang ditawarkan, dimulai dari program yang paling mudah dan dapat dilaksanakan segera.

\section{C.HASIL DAN PEMBAHASAN}

Kegiatan pengabdian kepada masyarakat dengan judul Program Kemitraan Masyarakat (PKM) peningkatan pengetahuan dan ketrampilan membuat minuman Jasule (jahe susu lemon) pada masyarakat untuk meningkatkan imunitas yang berguna saat pandemi Covid19 di Desa Pangkalan Jati Cinere Depok dilaksanakan pada hari Kamis 13 Agustus 2020. Kegiatan ini dihadiri oleh 10 peserta dengan menerapkan protokol kesehatan dengan menggunakan masker, memakai handsanitizer dan menjaga jarak. Kegiatan penyuluhan dan pelatihan berjalan dengan 
baik, peserta penyuluhan adalah ibu-ibu Desa Pangkalan Jati Cinere Depok.

Peserta penyuluhan dan pelatihan menunjukkan minat terhadap materi yang diberikan, dengan antusias mendengarkan dan mengajukan pertanyaan. Metode penyuluhan menggunakan media power point dan praktek pelatihan membuat minuman jasule Jahe Susu Lemon. Kegiatan diawali dengan pengisian pre test untuk mengetahui seberapa jauh pemahaman peserta tentang pelatihan ini. Setelah itu dilanjutkan dengan penyuluhan dan pelatihan pembuatan minuman jasule. Disela sela penyuluhan dan pelatihan, peserta juga mengajukan beberapa pertanyaan dan penyuluh memberikan jawaban serta pendampingan dan contoh pelatihan melalui praktek langsung pembuatan minuman Jasule.

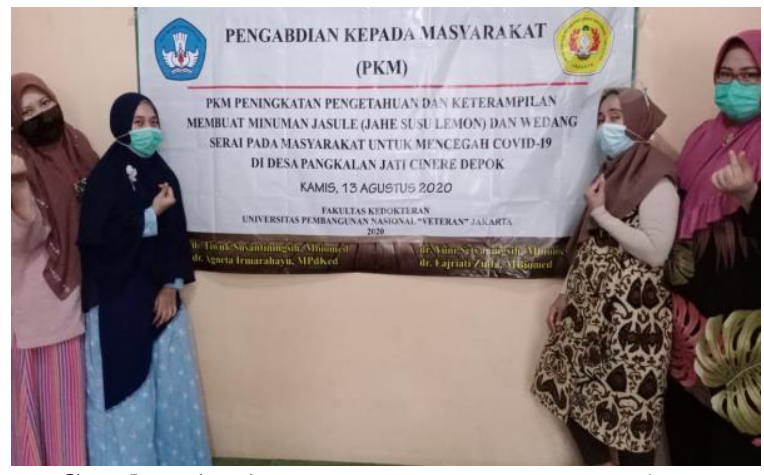

Gambar 1. Tim PKM FK UPNVeteran Jakarta

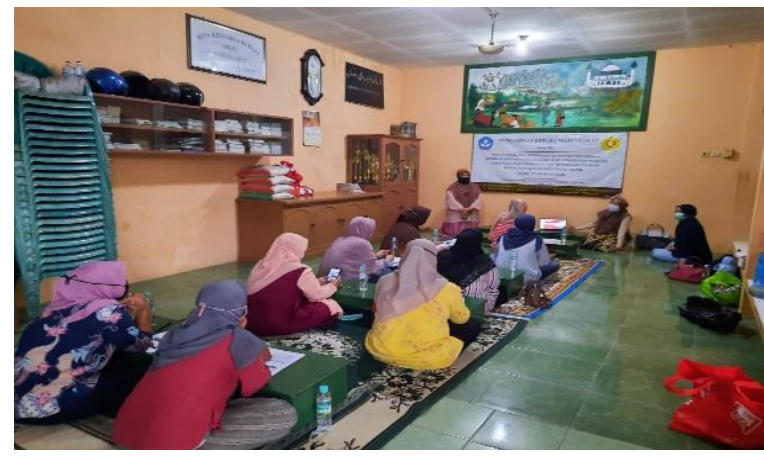

Gambar 2. Kegiatan Pretest dan Penyuluhan Pelatihan Pembuatan minuman Jasule di Desa Pangkalan Jati Cinere Depok.
Penyuluhan diakhiri dengan post test untuk mengetahui apakah pemahaman peserta menjadi lebih baik, dengan menggunakan soal yang sama dengan soal pretest. Peserta penyuluhan ini adalah ibu-ibu dengan usia 40-60 tahun. Distribusi usia perserta penyuluhan dan pelatihan dapat dilihat pada diagram berikut.

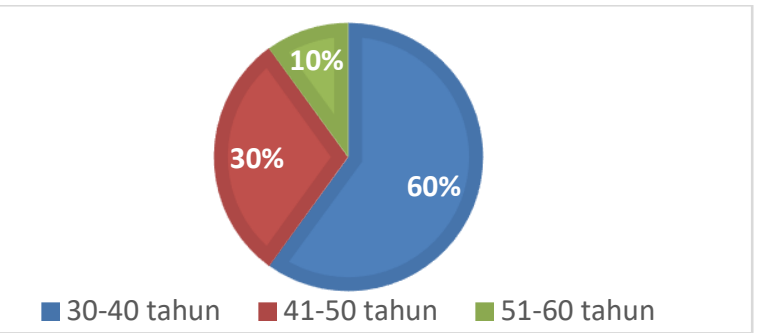

Gambar 3. Distribusi usia peserta pelatihan dan penyuluhan pembuatan minuman Jasule di Desa Pangkalan Jati, Cinere Kota Depok

Dari diagram tersebut terlihat bahwa peserta berusia terbanyak antara 30-40 tahun. Peserta penyuluhan masih dalam usia produktif, diharapkan dapat menyebarkan pengetahuan dan ketrampilannya dalam membuat minuman jasule terutama kepada anggota keluarganya serta kepada masyarakat sekitar di Desa Pangkalan Jati Cinere Depok.

Tingkat pendidikan peserta penyuluhan dapat dilihat pada diagram berikut (Gambar 4). Mayoritas peserta penyuluhan memiliki tingkat pendidikan SMA yaitu 9 orang. Dari distribusi tingkat pendidikan ini sebagian besar peserta mengenyam tingkat pendidikan SMA. Hanya 1 yang berpendidikan terakhir sarjana D3. Dari tingkat Pendidikan yang rata rata adalah lulusan SMA, diharapkan mempunyai tingkat Pendidikan yang cukup untuk dapat menerima pelatihan dan dapat menyebarkan hasil pelatihan ini kepada anggota keluarga dan anggota masyarakat secara luas. 
Sedangkan untuk yang berpendidikan D3 ada 1 orang.

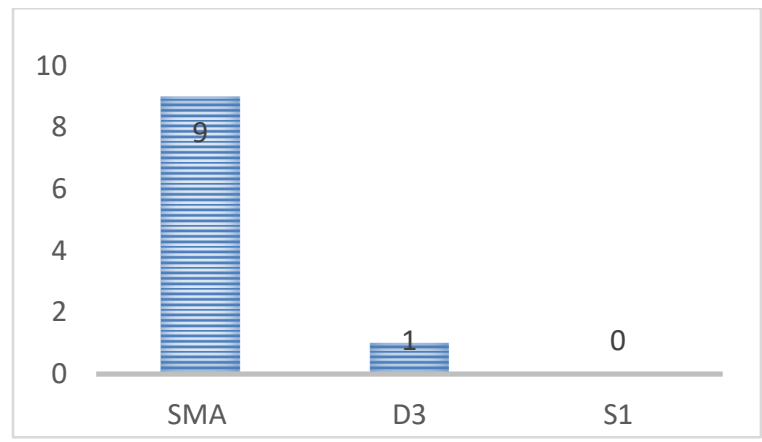

Gambar 4. Distribusi Tingkat Pendidikan Peserta Penyuluhan dan pelatihan Pembuatan minuman Jasule di Desa Pangkalan Jati Cinere, Kota Depok

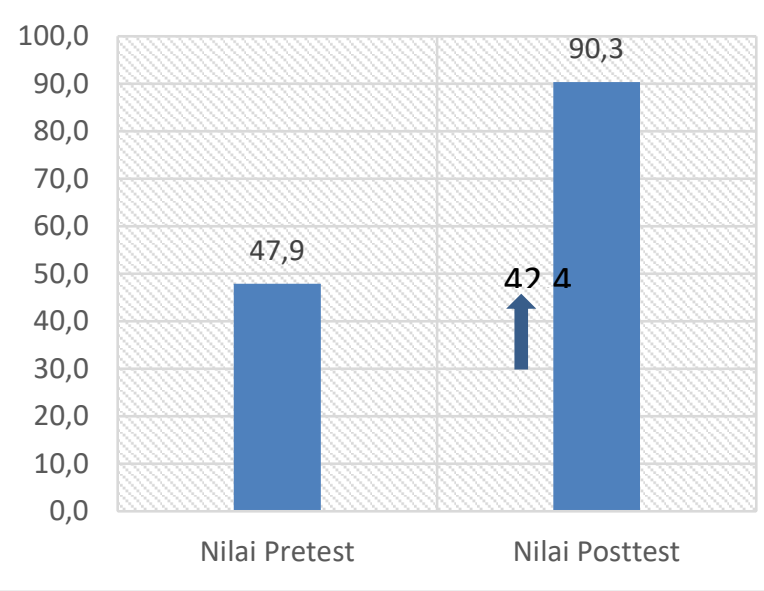

Gambar 5. Perbandingan nilai pretest dan posttest PKM peningkatan pengetahuan dan ketrampilan membuat minuman Jasule (Jahe Susu Lemon) pada Masyarakat untuk meningkatkan imunitas dimasa Pandemi Covid-19 di Desa Pangkalan Jati Cinere Depok

Dari kegiatan penyuluhan dan pelatihan pembuatan minuman Jasule, nilai posttest peserta mengalami peningkatan, seperti yang terlihat dalam Gambar 4. Dari Gambar 5 di atas terlihat bahwa pada saat pretest, bahwa nilai rata rata peserta adalah $47,9 \%$ dan masih dianggap rendah. Hal ini terlihat dari beberapa pertanyaan yang dijawab belum pernah. Peserta belum pernah mengikuti pelatihan pembuatan minuman jasule dan belum mengetahui manfaat tanaman obat dari jahe dan lemon. Peserta memang belum pernah membuat minuman herbal jasule. Belum pernah mendengar adanya informasi tentang pemanfaatan minuman jasule untuk meningkatkan imunitas tubuh dalam melawan pandemi Covid-19 ini (Sosialisasi, 2019).

Beberapa pertanyaan dalam soal pretest adalah: Apakah Ibu pernah mengikuti pelatihan pembuatan minuman Jasule? Apakah yang Ibu ketahui tentang Covid-19? Siapa saja yang bisa terinfeksi Covid-19? Bagaimana cara mencegah infeksi Covid-19 di rumah? Apakah yang Ibu ketahui tentang Minuman Jasule? Apakah kandungan dan fungsi Jahe yang Ibu ketahui? Apakah Ibu menanam Jahe di rumah sebagai TOGA? Apakah kandungan dan fungsi lemon yang Ibu ketahui? Apakah Ibu menanam lemon di rumah sebagai TOGA ?.

Kegiatan Penyuluhan dan Pelatihan pembuatan minuman Jasule untuk meningkatkan imunitas di masa Pandemi Covid-19. Penyuluhan mengguna-kan media power point dan alat peraga. Pada power point dipaparkan mengenai Covid-19, siapa saja yang bisa terkena dan bagaimana cara meningkatkan imunitas tubuh dengan bahan bahan tanaman obat yang ada di sekitar rumah, misalnya jahe dan lemon. (Wardyaningrum, 2011). Kemudian peserta juga diajarkan cara membuat minuman Jasule. Satu persatu peserta membuat minuman Jasule sampai benar benar bisa mengerjakannya dengan benar. Selama penyuluhan dan pelatihan, peserta juga melakukan tanya jawab kepada penyuluh. Penyuluh menjawab sampai peserta benar benar paham. Kegiatan Post test setelah dilakukan penyuluhan 
Setelah kegiatan penyuluhan dan pelatihan selesai dilakukan maka dilakukan pengambilan post test dengan soal yang sama dengan pre test. Post test bertujuan untuk mengetahui apakah terdapat peningkatan pengetahuan dan ketrampilan peserta penyuluhan setelah dilakukan penyuluhan dan pelatihan pembuatan minuman Jasule untuk meningkatkan imunitas di masa pandemic Covid-19. Dari hasil post test didapatkan hasil rerata nilai post test peserta meningkat menjadi 90,3\%, sehingga terdapat peningkatan nilai dibandingkan nilai pre test yaitu $42,4 \%$.

Kasus penyakit virus corona (COVID-19) di Indonesia bertambah dari hari ke hari. Tercatat per tanggal 7 Mei 2020 sudah terdapat 12.776 pasien positif virus corona dengan menyebabkan kematian terhadap 930 pasien sementara 2.381 tercatat telah sembuh. Data ini terus berkembang seiring waktu. Peningkatan pasien COVID19 disebabkan virus corona yang mudah menyebar ke manusia melalui berbagai perantara. Virus corona bisa menular dari penderita melalui kontak kulit seperti jabat tanga, cium pipi, atau berpelukan (Riadi, 2019; Susilo et al., 2020).

Virus corona yang menempel di berbagai permukaan barang seperti pegangan pintu, tangga, kertas, meja, sendok, dan kardus juga bisa menular ke manusia jika ada sentuhan tangan dengan benda benda tersebut kemudian tangan menyentuh wajah. (UNICEF, 2020).

Di saat pandemi covid-19 seperti sekarang ini, masyarakat harus mampu menjaga kesehatan agar tidak tertular virus. Salah sataunya adalah dengan meningkatkan imunitas tubuh. Ada berbagai upaya yang perlu dilakukan untuk meningkatkan imunitas tubuh. Cara meningkatkan imunitas tubuh salah satunya adalah dengan mengkonsumsi banyak makanan yang baik untuk sistem kekebalan tubuh, salah satunya adalah minuman herbal Jasule. Selain tentu saja $3 \mathrm{M}$ yaitu memakai masker, mencuci tangan dengan sabun dan air yang mengalir, serta menjaga jarak (Riadi, 2019).

Dalam pelatihan ini peserta penyuluhan diberikan materi tentang pentingnya kandungan minuman herbal Jasule. Pentingnya menanam jahe dan lemon sebagai salah satu tanaman obat di pekarangan. Serta diberikan pelatihan pembuatan minuman Jahe Susu Lemon sampai semua peserta benar benar bisa membuatnya sendiri (Dhir et al., 2017; Hari Wijayanto, 2020; Masker et al., 2020).

Diharapkan dengan kegiatan penyuluhan dan pelatihan pembuatan minuman herbal Jasule ini, peserta pelatihan dapat meningkat tingkat pengetahuan dan ketrampulannya dalam pembuatan minuman herbal Jasule, dalam meningkatkan imunitas tubuh dimasa pandemic Covid-19 ini. Hal ini terlihat adanya peningkatan nilai posttest peserta yang meningkat sebanyak $42,4 \%$ dibandingkan dengan nilai pretest.

\section{PENUTUP}

\section{Simpulan}

Kegiatan penyuluhan dan pelatihan pembuatan minuman herbal Jasule untuk meningkatkan imunitas tubuh dimasa Pandemi Covid-19 di Desa Pangkalan Jati Cinere Depok dapat diterima dengan baik oleh peserta penyuluhan terlihat dengan antusiasme dan pertanyaan yang diajukan. Peserta mendapatkan tambahan pengetahuan dan ketrampilan dalam membuat minuman herbal Jasule dapat dilihat dengan terdapatnya peningkatan nilai post test setelah dilakukan penyuluhan dan pelatihan pembuatan minuman herbal Jasule untuk meningkatkan imunitas tubuh dimasa Pandemi Covid-19 di Desa Pangkalan Jati Cinere Depok sebesar $42,4 \%$ yaitu dari $47,9 \%$ menjadi $90,3 \%$. 


\section{September.}

\section{Saran}

Perlu dilakukan kegiatan PKM ini secara rutin agar tingkat pengetahuan dan ketrampilan masyarakat tentang cara meningkatkan imunitas tubuh di masa pandemi Covid-19 meningkat.

\section{Ucapan Terima Kasih}

Terimakasih kepada masyarakat Desa Pangkalan Jati Cinere Depok yang sudah berperan dalam kegiatan pengabdian kepada masyarakat ini.

\section{E. DAFTAR PUSTAKA}

Dhir, S. K., Verma, D., Batta, M., \& Mishra, D. (2017). E-learning in medical education in India. Indian Pediatrics, 54(10), 871-877.

Hari Wijayanto. (2020). No TitleHari Wijayanto. In IPB Today (pp. 1-16).

Kemenkes. (2020). Final-Panduan-GiziSeimbang-Pada-Masa-Covid-19-1.Pdf. In Panduan Gizi Seimbang Pada Masa Pandemi COVID-19 (p. 31).

Kusuma, T. M., Wulandari, E., Widiyanto, T., \& Kartika, D. (2020). Hubungan Tingkat Pengetahuan dan Sikap terhadap Kebiasaan Konsumsi Jamu pada Mayarakat Magelang Tahun 2019. Pharmacon: Jurnal Farmasi Indonesia, O(0), 37-42.

Masker, P., Tangan, C., \& Sabun, P. (2020). Pedoman edukasi perubahan perilaku.
Riadi, A. (2019). Pedoman dan Pencegahan Coronavirus (COVID- 19). Math Didactic: Jurnal Pendidikan Matematika, 4, 1-214.

Sosialisasi, B. (2019). IPB Today. 216(0251), $1-9$.

Susilo, A., Rumende, C. M., Pitoyo, C. W., Santoso, W. D., Yulianti, M., Herikurniawan, H., Sinto, R., Singh, G., Nainggolan, L., Nelwan, E. J., Chen, L. K., Widhani, A., Wijaya, E., Wicaksana, B., Maksum, M., Annisa, F., Jasirwan, C. O. M., \& Yunihastuti, E. (2020). Coronavirus Disease 2019: Tinjauan Literatur Terkini. Jurnal Penyakit Dalam Indonesia, 7(1), 45.

UNICEF. (2020). COVID-19 dan AnakAnak di Indonesia Agenda Tindakan untuk Mengatasi Tantangan Sosial Ekonomi. Journal of Education, Pshycology and Counseling, 2(April), 1-12. www.unicef.org

Wardyaningrum, D. (2011). Tingkat Kognisi Tentang Konsumsi Susu Pada Ibu Peternak Sapi Perah Lembang Jawa Barat. Jurnal Al-Azhar Indonesia Seri Pranata Sosial, 1(1), 19-26. 